\title{
A recepção crítica de Clarice Lispector: momentos decisivos
}

\author{
Diego Miiller Fascina* \\ Alice Áurea Penteado Martha**
}

\section{Resumo}

O presente trabalho traz reflexões a respeito da recepção crítica sobre a obra de Clarice Lispector em três momentos: seu surgimento profissional, com Perto do Coração Selvagem, em 1944 , romance de estreia que inaugura um novo estilo de narrativa até então desconhecido em nosso país; o ponto alto de sua carreira, com a publicação da coletânea Laços de $F a$ mília, em 1960, e com o romance $A$ paixão segundo G.H., em 1964, textos de sua fase madura, que cristalizam todas as características formais e as preocupações existenciais que a colocariam entre os principais nomes de nossa história literária, e finalmente, com uma de suas últimas publicações, A via crucis do corpo, de 1974, na qual a preocupação de escrever por encomenda pareceu à crítica um declínio no valor estético e nas características e técnicas que permearam sua escrita durante toda sua obra.

Plavras-chave: Clarice Lispector. Crítica literária. Recepção literária.

\section{Introdução}

Ler Clarice Lispector continua sendo um desafio tanto para os analistas de literatura quanto para os leitores comuns. Não porque ela seja uma escritora difusa ou complexa estilisticamente, mas porque, na enganosa facilidade de entendimento de seus textos, esconde-se um registro literário fascinante e sempre aberto a novas descobertas.

Yudith Rosenbaum (2002, p. 8) afirma que a obra da autora é vista até hoje como "uma experiência, no limite, indecifrável, seja para seu público cativo, seja para os que dela se aproximam pela primeira vez". Tentar mensurar sua importância, não apenas como escritora que, a seu modo, renovou as letras brasileiras,

\footnotetext{
Doutorando em Letras, na área de Estudos Literários do Programa de Pós-Graduação em Letras da Universidade Estadual de Maringá. diegomullerfascina@hotmail.com

** Docente do Programa de Pós-Graduação em Letras da Universidade Estadual de Maringá. apmartha@uol. com.br
}

Data de submissão: mar. 2015 - Data de aceite: maio 2015 http://dx.doi.org/10.5335/rdes.v11i1.4976 
mas também como influência de parte significativa do que encontraríamos mais tarde em nosso plano literário é inútil. Por mais estudos que sejam arrolados, sempre ficará muito por dizer; "literatura é novidade que se mantém novidade", disse Ezra Pound ${ }^{1}$ (2006, p. 33).

No caso de Lispector, a inovação operada ao organizar a estrutura de uma narrativa descontínua, que obriga a uma reflexão sobre a linguagem literária e seus mecanismos de representação da realidade, provoca em muitos uma reação pouco positiva, tamanha a novidade que sua obra mantém. Isso se dá porque refletir a respeito desse tecido complexo, a densa corporeidade da qual é feita o seu discurso, tem seu ato de criação finalizado na leitura. Em outras palavras, a escritura de quem afirma "estou tentando escrever-te com o corpo todo" (LISPECTOR, 1994, p. 11) só pode ser lida por "aqueles que sabem que a aproximação do que quer que seja se faz gradual e penosamente - atravessando inclusive o oposto daquilo que se vai encontrar" (LISPECTOR, 1998, p. 5).

Essas novidades, muitas vezes, são difíceis de serem percebidas sem o intermédio da crítica literária. Saint-Beuve (apud ARRIGUCI JÚNIOR, 1994) observa que o crítico literário é o que sabe ler e ensinar os outros a ler, isto é, ensinar ou ler literatura sem se preocupar com a crítica literária é uma tarefa bastante problemática e os motivos, com o passar do tempo, tornaram-se óbvios: pelo filtro da crítica, o leitor ganha condições de julgamento mais criteriosos e menos impressionistas, os juízos de valor proferidos pela crítica colaboram decisivamente para fixar o gosto do leitor, para eternizar ou fazer esquecer o texto, além dela funcionar como ferramenta esclarecedora de textos que, muitas vezes, não se fazem lúcidos a uma "leitura despreparada".

Reiterando as palavras de Saint-Beuve, Roland Barthes diz, em Crítica e Verdade (2003) ${ }^{2}$, que a crítica é um discurso que tem a intenção de dar um sentido todo próprio à obra e que, por isso, é diferente da leitura e sua tarefa não é absolutamente descobrir verdades, mas somente validades, ou seja, não consiste em descobrir na obra ou no autor observado alguma coisa de secreto que teria passado despercebido, mas somente em ajustar, como um bom marceneiro, que aproxima apalpando inteligentemente duas peças de um móvel complicado, a linguagem que lhe fornece sua época (o existencialismo, o marxismo, a psicanálise, por exemplo) ao sistema formal de constrangimentos lógicos elaborados pelo próprio autor segundo sua época, preocupando-se não em homenagear a verdade do passado, ou a verdade do outro, mas, sim, em construir a inteligência de seu tempo.

Northrop Frye afirma em sua Anatomia da Crítica (1973) que a matéria da crítica literária é arte, e a crítica, evidentemente, é também uma espécie de arte. Arte parasitária, pois se baseia em outra já existente, no caso a literatura. Frye diz 
que o crítico é um sujeito que mantém um discurso intelectual e que assume não apenas o papel de escrevente (aquele para quem a linguagem é um mero instrumento); é também escritor (aquele para quem a linguagem representa um problema), daí a crítica ser considerada arte. E ela precisa existir, porque ela pode falar, e todas as artes são mudas.

É, portanto impossível estudar literatura: uma pessoa a aprende em certo sentido, mas o que se aprende transitivamente é a crítica de literatura (grifo nosso). Similarmente, a dificuldade que amiúde se sente de ensinar literatura nasce do fato de que isso não pode ser feito: a crítica da literatura é tudo o que pode ser ensinado diretamente. A literatura não é disciplina de estudo, mas objeto de estudo (FRYE, 1973, p. 19).

Frye nos diz ainda que a função da crítica é procurar a melhor leitura para a obra e, consequentemente, para melhor entendimento do mundo. A leitura crítica não se concentra apenas na busca prazerosa da função textual. Sua função é analítica, de busca da estrutura do texto, desmontando-o como se faz a um corpo humano em uma aula de anatomia.

As contribuições de Barthes (2003, 2004) e Frye (1973) nortearão as discussões propostas neste trabalho ao lado de alguns conceitos teóricos da estética da recepção de Hans Robert Jauss (1994). Partindo desse início de reflexão, nossa intenção é realizar um mapeamento das vozes decisivas da crítica literária na obra de Clarice Lispector, especialmente nos três distintos momentos, já citados: sua recepção inicial, em 1944, com Perto do Coração Selvagem, romance que funda um estilo de narrativa até então novo nas letras brasileiras; a publicação da coletânea Laços de Família, em 1960, e o romance A paixão segundo G.H., em 1964 , textos que amadurecem esse estilo e demais preocupações temáticas traçadas em seu surgimento; e, finalmente, os contos de A via crucis do corpo, coletânea publicada originalmente em 1974, em que, prevendo e temendo as palavras da crítica, a escritora recorre ao prefácio do livro para afirmar: "Vão me jogar pedras. Sou mulher séria” (LISPECTOR, 1998a, p. 11), isso porque ao escrever por encomenda, Clarice percebeu a queda no valor estético de sua obra, o que geraria algumas polêmicas, como se verá mais adiante.

Levando em consideração que o crítico também é um artista, teceremos algumas informações a respeito dos teóricos que foram fundamentais, especialmente nesses três momentos que aqui serão discutidos. Julgamos importante salientar, que, apesar de os tópicos trazerem no próprio título, o nome desses teóricos, contribuições de outros estudiosos serão adicionadas, a fim de sedimentarmos e reforçarmos a importância dessas vozes iniciais.

\section{Antonio Candido e o raiar de Clarice Lispector}

O surgimento profissional de Clarice Lispector, em 1944, com a publicação de seu primeiro romance Perto do Coração Selvagem foi uma surpresa, tanto para os leitores, não habituados com a temá- 
tica e com as técnicas utilizadas pela autora, quanto para os críticos da época. Na contramão das tendências literárias vigentes da década de 1940, a autora insurge contra a linearidade narrativa, num momento literário em que a linguagem seguia uma concatenação lógica para expressar e denunciar os problemas histórico-sociais de nosso país.

A primeira voz abalizada da crítica é de Antonio Candido. Como diz Leyla Perrone-Moisés (2000), falar da importância desse crítico para a literatura brasileira é "chover no molhado". Ela afirma que ler Antonio Candido é algo que todos os críticos ou aspirantes a crítico deveriam fazer regularmente, pois sempre há muito que se aprender com ele.

Dentre as qualidades que fazem de A.C. um crítico modelar, eu destacaria as seguintes: 0 amor à literatura, que o faz valorizar o texto mais do que o contexto, o objeto mais do que o método; a enunciação delicada de suas avaliações, que nunca se apresentam como juízos de verdade, definitivos e indiscutíveis; o reconhecimento de valores estéticos independentes dos valores éticos e políticos. Essas são qualidades que podem ser aprendidas e cultivadas por quem se dispuser a tomá-las como exemplares (PERRONE-MOISÉS, 2000, p. 329).

Outras qualidades que não podem ser ensinadas são aquelas que Candido utilizou para saudar a primeira obra de Clarice: a sensibilidade e a capacidade de reconhecer imediatamente, dentre os escritores contemporâneos, aqueles que o tempo confirmaria como fundamentais. Ezra Pound, em seu Abc da Literatura (2006), afirma que o crítico e os artistas em geral são as antenas da raça, pois ficam excitados e "super excitados" pelas coisas muito antes do público em geral. Foi o que aconteceu com Antonio Candido. Em um artigo significativamente intitulado No raiar de Clarice Lispector, publicado logo após o surgimento do romance, Candido, um crítico já respeitado apesar da pouca idade, realiza um estudo que é um ato de compreensão à jovem escritora, mostrando o espanto diante da novidade de seu estilo. Realizando sua função de crítico, Candido recebe a primeira obra de Clarice e suas entusiasmadas palavras diante do novo, eternizam o romance:

Tive verdadeiro choque ao ler o romance diferente que é Perto do Coração Selvagem, de Clarice Lispector, escritora até aqui completamente desconhecida para mim. Com efeito, este romance é uma tentativa impressionante para levar a nossa língua canhestra a domínios pouco explorados, forçando-a a adaptar-se a um pensamento cheio de mistério, para o qual sentimos que a ficção não é um exercício ou uma aventura afetiva, mas um instrumento real do espírito, capaz de nos fazer penetrar em alguns dos labirintos mais retorcidos da mente [...] (p. 127). Clarice Lispector nos deu um romance de tom mais ou menos raro em nossa literatura moderna [...] dentro de nossa literatura é performance da melhor qualidade [...] (p. 128). A intensidade com que sabe escrever e a rara capacidade da vida interior poderão fazer desta jovem escritora um dos valores mais sólidos e, sobretudo, mais originais de nossa literatura, porque esta primeira experiência já é uma nobre realização (CANDIDO, 1970, p. 131).

Candido completa dizendo que a jovem estreante se aproximava de uns poucos violadores da rotina literária, tais como Mário de Andrade, com Macunaíma, ou Oswald de Andrade, com Memórias 
sentimentais de João Miramar, que conseguiram entender o domínio da palavra sobre regiões mais complexas e mais inexprimíveis, ou fazer da ficção uma forma de conhecimento do mundo das ideias. Talvez tenha sido antes de tudo esse aspecto do romance que o próprio Oswald de Andrade perceberia ao colocar, entre os continuadores das altas cogitações estéticas da semana de Arte Moderna de 22, Clarice Lispector ao lado de Guimarães Rosa.

$\mathrm{Na}$ esteira de Candido, Sérgio Milliet também saúda a estreia da escritora. Milliet (apud SÁ, 1979, p. 24) afirma que diante daquele nome desagradável, pseudônimo sem dúvida, pensou estar diante de mais uma dessas mocinhas que principiam cheias de qualidade, mas que morreriam de ataque diante de uma crítica séria. Porém, ao ler efetivamente o romance, publica em seu Diário Crítico, no dia 11 de março de 1944, as seguintes palavras:

Mas isso é excelente! Que sobriedade, que penetração, e ao mesmo tempo, apesar do estilo nu, que riqueza psicológica! Leio ainda alguns trechos numa espécie de teste e resolvo começar. O primeiro capítulo confirma as impressões anteriores, e sigo lendo, sem parar mais, tomado de um interesse que não decai, que encontra novas vitaminas nas constantes observações profundas, cristalinas e duras de Joana, na sua capacidade introspectiva, na coragem simples com que compreende e expõe a trágica e rica aventura da solidão humana. Clarice Lispector tem o dom de dar as palavras, uma vida própria. Ela as cria, nesse sentido de emprestar-lhes um conteúdo novo, inesperado, que acaba espantando a criadora e lhe enchendo o espírito de fantasmas. Não as domina mais, então; elas é que tomam conta dela (MILLIET, 1981, p. 28).
Acionando os conceitos de horizonte de expectativas ${ }^{3}$ e de distância estética ${ }^{4}$, oriundos da crítica de Jauss (1994), podemos ilustrar com mais rigor, a recepção inicial da autora. $\mathrm{O}$ "choque" acima descrito pelo já supracitado Candido (1970) nos mostra que a distância estética entre os horizontes de expectativa (do público e da obra) é extremamente aumentada, uma vez que Perto do coração selvagem contrariou as experiências habituais dos romances regionalistas de 1930 e conscientizou o leitor para experiências não expressadas ainda. Trata-se de um acontecimento literário e, segundo nos informa Sá (1979), foram necessários 20 anos para que, apenas em 1963, em uma edição popular, esse romance fosse divulgado para um público cativo e mais acostumado com o estilo de Lispector. Dessa data em diante, a distância entre as edições foi, sucessivamente, se encurtando, todavia, lançando mão de Jauss (1994), a estreia da autora continua sendo uma grande obra, pois, passando mais de setenta anos de seu lançamento, continua a provocar o leitor, permitindo novas leituras, independentemente do momento histórico.

Ainda abordando a recepção inicial de Perto do coração selvagem, Candido e Milliet preocuparam-se em marcar as diferenças de sua linguagem e não estabeleceram crítica a seu desempenho criador. O crítico foi Álvaro Lins. Em um artigo intitulado $A$ experiência incompleta: Clarice Lispector, sobre os romances Perto do Coração Selvagem (1944) e $O$ Lustre (1946), o crítico não 
deixa de reconhecer a originalidade e os méritos da escritora, mas considera $o$ romance como incompleto e inacabado, sem unidade interna, já que se sustenta mais por situações isoladas do que pelo conjunto, apontando, dessa maneira, a distância estética existente em seu horizonte de expectativas.

Romances, porém, não se fazem somente com um personagem e pedaços de romances, romances mutilados e incompletos, são os dois livros publicados pela Sra. Clarice Lispector, transmitindo ambas nas últimas páginas a sensação de que alguma coisa essencial deixou de ser captada ou dominada pela autora no processo da arte de ficção (LINS, 1963, p. 192).

Lins (apud SÁ, 1979, p. 29) situa o livro na categoria do que ele chama de literatura feminina. Às características do temperamento feminino (potencial de lirismo, narcisismo) atribui à presença visível e ostensiva da personalidade da autora, em primeiro plano, na protagonista Joana. Segundo Lins, Perto do Coração Selvagem é um romance original nas nossas letras, embora não o seja na literatura universal (arriscando a crítica de influências negada por Candido):

Não tenho receio de afirmar, todavia que o livro da Sra. Clarice Lispector é a primeira experiência definida que se faz no Brasil do moderno romance lírico, do romance que se acha dentro da tradição de um Joyce ou de uma Virgínia Woolf (LINS, 1963, p. 193).

No final de seu artigo, Lins informado de que a escritora estreante é jovem, reconhece-lhe um poder de inteligência acima de sua idade, mas denuncia a falta de experiência vital, que vem do tempo e da intuição necessária ao romancista.
Clarice ficou muito abalada, porém era previsível a reação, levando-se em conta que vários de seus leitores e críticos, incluindo Álvaro Lins, estavam acostumados a uma forma romanesca acabada e linear.

Olga de Sá aponta que não ocorreu a Álvaro Lins, que um romance novo, fora dos moldes tradicionais, como ele mesmo o reconhece, recusaria uma trama com início, meio e fim e poderia terminar com um longo monólogo da protagonista, "aberto" para as possibilidades que oferece a cavalgada no cavalo novo, à procura do selvagem coração da vida. O crítico, no dilema de perceber uma originalidade, como foi o caso, mas não conseguir situá-la, refugia-se, então, no álibi da idade da autora, de sua falta de experiência humana (SÁ, 1979, p. 30). As palavras de Lins reforçam a novidade da ficção clariceana e o despreparo crítico para a recepção de tal obra, causando, o que Jauss (1994), emprestando dos formalistas russos, chamaria de estranhamento.

Após a publicação de Perto do Coração Selvagem, Clarice Lispector lança os romances $O$ Lustre, em 1946, e A cidade sitiada, em 1949. Em função de um casamento com um diplomata brasileiro, a escritora vai acompanhar o marido em suas andanças pelo mundo e em razão disso se cria um hiato de onze anos sem publicações.

A crítica não se posicionou diferente mediante a publicação desses dois romances. Gilda de Mello e Souza (apud SÁ, 1979, p. 32) mescla em seu ensaio, 
intitulado $O$ Lustre, as já citadas palavras de Candido e de Lins. Concorda que Clarice Lispector é uma escritora original, ambiciosa, possuidora de enorme talento e rara personalidade, porém, seu segundo romance, traia, de certa maneira, a característica principal do romance que é ser romanesco e discursivo. Nesse ponto, ela concorda com Lins, ressaltando a mutilação do romance e, dessa vez, compara Lispector com Kafka, como Lins havia feito anos atrás, comparando-a com Joyce e Woolf. Com esse posicionamento, o que novamente se percebe é o aumento da distância estética, resultando na dificuldade em receber um modelo romanesco inovador.

Milliet também comenta o novo livro de Clarice, comparando-o com Perto do Coração Selvagem e temendo que a forma se transforme em fórmula.

Do ponto de vista psicológico observa-se em Lustre, novo romance de Clarice Lispector a mesma procura de fixação do imponderável e do diferente que caracteriza Perto do Coração Selvagem. Neste romance como no segundo publicado a heroína vive entre a sensualidade e o pessimismo. Em ambos o seu isolamento no mundo é total, a sua insolubilidade completa [...] (p. 40). Romance de uma envolvente tristeza é, no entanto esse livro uma obra de amor, de extravasamento de amor, de plenitude emocional admirável. E servida por um estilo exuberante de imagens, em que a volúpia da palavra, da frase, o som e da cor se expande numa permanente, e por vezes exaustiva sinfonia [...] Há, porém um perigo de tocaia, o perigo da fórmula, que a autora precisa obviar e que não raro a atraiçoa no seu último romance. O estilo é sem dúvida o grande trufo de Clarice Lispector, mas é também a sua maior possibilidade de perdição (MILLIET, 1980, p. 41).
O mesmo crítico, que saudava anos antes a riqueza psicológica de Perto do Coração Selvagem, afirma agora que a química sintáxica do estilo clariceano estava fadada a perder sua originalidade. Ao ler o terceiro romance, $A$ cidade sitiada, Milliet afirma que Clarice confundia-se na teia de suas imagens, que se sucedem nesse romance sem objetivo certo, pelo prazer da frase, da exibição de um requinte. Verbiagem, malabarismo, exibicionismo insistente, achados de romancista, eis os graves defeitos desse romance. Apesar disso, o crítico reafirma que Clarice Lispector é uma escritora de grande talento, cujo estilo se desdobra a serviço de um temperamento feito de curiosidade sensual e de sensibilidade angustiada (SÁ, 1979, p. 26).

$\mathrm{O}$ que Lins e Milliet, desnorteados com os primeiros textos de Lispector, chamam de defeitos na estrutura da composição dos romances, isto é, a colocação do tempo e espaço no plano da descontinuidade, é precisamente o que Benedito Nunes apontará mais tarde como o ponto de maior força da escritora.

\section{Benedito Nunes e o formigamento da existência}

Benedito Nunes foi quem, até hoje, fez estudos de mais longo fôlego acerca da obra de Clarice Lispector. Seu primeiro ensaio intitulado $O$ mundo de Clarice Lispector, publicado em 1966, é uma crítica que valoriza a obra de Lispector, 
questionando os estudiosos que não conseguiam ver a importância de certos temas e situações, constantes na obra da escritora brasileira e chama a atenção para isso logo na introdução:

Este ensaio é uma tentativa para interpretar coerentemente a ficção de Clarice Lispector, cuja importância cresceu muito, sobretudo depois do aparecimento de A maçã no escuro (1961). A paixão segundo G.H., de 1964, recebido pela crítica com respeitoso silêncio, quebrado por uma ou outra apreciação, ainda não foi devidamente avaliado quanto ao lugar que ocupa na prosa de ficção da extraordinária escritora (grifo nosso). Houve mesmo, a propósito desse último romance de Clarice Lispector, reações de surpresa e de estarrecimento. Chegou-se até a falar no hermetismo da autora, de seu culto de vaguidão, e da incomunicabilidade final dos propósitos da romancista (NUNES, 1966, p. 11).

Apesar de não ter sido o primeiro a analisar a produção da autora, parece ter sido Benedito Nunes quem mais se encantou naquele momento com sua escrita, debruçando-se por toda sua vida sobre a obra dela. Percebe-se em sua análise que, em nenhum momento, Nunes fez menção ou tratou com inferioridade a obra de Clarice por ser mulher, ao contrário de Álvaro Lins:

Este tipo de criação literária não se ajusta muito bem os temperamentos femininos; e talvez seja essa uma razão capaz de explicar porque a escola realista e a escola naturalista não foram propícias às mulheres escritoras, salvo um ou outro caso de inteligência (LINS, 1963, p. 186).

Em uma de suas raras entrevistas, Clarice Lispector é questionada pelo repórter:
A experiência mística de A paixão segundo G.H. que um crítico chamou de encontro da consciência com a realidade última termina pelo silêncio, implicando assim na desistência da compreensão da linguagem.

\section{Clarice respondeu prontamente:}

Benedito Nunes, não é? Ele é muito bom. Ele me esclarece muito sobre mim mesma. Eu aprendo sobre o que escrevi (grifo nosso) (SÁ, 1979, p. 189).

Embora a afirmação pareça irônica, esta parece ser a grande função de um crítico literário: propor até ao próprio autor múltiplas visões de sua obra e ainda criar mecanismos para que venham à tona essas inúmeras leituras. Benedito Nunes, um crítico preparado com os instrumentos da lógica e da filosofia, era, para a autora, o algo que ela não sabia explicar, diferente do crítico comum. Devido à sua acuidade especulativa, Nunes encontra seu método de análise na própria espessura psicofilosófica do texto clariceano. Talvez os aplicadores mecânicos de conceitos de linguistas, mitólogos, antropólogos e psicanalistas, ou de modelos derivados, jamais pudessem iluminar e interpretar tão bem a obra de Lispector.

Chegamos aqui, ao segundo momento deste trabalho, em que a intenção é apontar o novo olhar que a crítica lançou para a ficção de Clarice Lispector, especialmente após as contribuições do filósofo paraense. A coletânea Laços de Família, publicada em 1960, obra que quebra o período de silêncio da escritora, instaurado desde o início de suas viagens pelo mundo, e o romance $A$ paixão 
segundo G.H., de 1964, são perfeitas ilustrações da consolidação de todas as questões formais e existenciais que se iniciam com Perto do Coração Selvagem, mas apenas com os posicionamentos de Nunes, são mais bem visualizadas e discutidas.

Como apontou Barthes (2003), a função do crítico, no caso Benedito Nunes, foi a de ajustar, como um marceneiro, a linguagem que fornece sua época, nesse contexto, o existencialismo, ao sistema formal da obra de Clarice Lispector. A obra da autora parece ter sido seu grande achado, pois o interesse maior de $\mathrm{Nu}$ nes era propor uma reflexão a respeito de filosofia e arte, em especial, a literatura. Com isso, o teórico lançou luzes à obra da escritora que, a partir de 1960, teve seus textos (re)lidos, reconfigurados e respeitados pela crítica. Seria, pois, na visão de Jauss (1994), uma genuína tentativa de reconstrução do horizonte de expectativas, para se conhecer a história do efeito, isto é, a maneira pela qual o próprio ato da compreensão da obra da autora está abarcado pela história e, dessa maneira, afetado pela maneira que esses textos são lidos.

Benedito Nunes (1966) analisa, inicialmente, três textos para comprovar a experiência da náusea no comportamento das principais personagens das obras escolhidas para discussão: Ana, protagonista do conto Amor, de Laços de Família (1960); Martim, do romance $A$ maçã no escuro (1961), e G.H., do romance A paixão segundo G.H. (1964), para mostrar a "concepção-do-mundo" de Clarice Lispector, ressaltando que

[...] é sempre possível encontrar na literatura de ficção, principalmente na escala do romance, uma concepção-do-mundo, inerente a obra considerada em si, concepção esta que deriva da atitude criadora do artista, configurando e interpretando a realidade (NUNES, 1966, p. 15).

Nas obras de Lispector, segundo Nunes, há afinidades marcantes com a filosofia da existência, deixando claro que essa sua percepção da filosofia existencial não fecha para outras possibilidades de análise. A partir de leituras de teorias sobre a náusea, a angústia e o medo, como as abordadas em Ser e tempo (1927), de Heidegger, O ser e o nada (1943) e A náusea (1938), de Sartre, e $O$ conceito de angústia (1844), de Kierkegaard, Benedito Nunes analisa a obra de Clarice Lispector, mostrando que temas importantes de seus textos podem ser elucidados por essas teorias.

Os teóricos que contribuíram para a fortuna crítica de Clarice, após 1960, compartilharam as ideias propostas por Benedito Nunes. A preocupação existencial, a sondagem psicológica, o enredo não linear, o uso do monólogo interior e do fluxo de consciência, dentre outras características, passaram a ser melhor entendidas e apreciadas. O estudo do filósofo abriu margens para novas discussões e a escritora, que até então tinha seus livros empoeirados nas estantes de bibliotecas, passa a ser objeto de estudo de muitos teóricos e principalmente passa a servir como fonte de inspiração 
para uma nova geração de escritores que vinha despontando naquela época. Seria, então, de fato, a reconstrução do horizonte de expectativas.

Seguindo os posicionamentos de Nunes, Massaud Moisés (1985) diz que literatura existencial, ou existencialista, eis o rótulo que se pode colar na obra de Clarice Lispector: os vocábulos "náusea", "nojo" e correlatos saltam-lhe da pena em certa fase de sua carreira, notadamente em Laços de Família. Ele completa, afirmando que

[...] o existencialismo em Clarice Lispector cumpre à risca o modelo psicológico inscrito nessa filosofia de vida: toda a sua obra, desde Perto do Coração Selvagem até os textos póstumos (ainda que narrados na terceira pessoa), espraia-se como um imenso monólogo, ou, com mais rigor, um solilóquio, uma vez que se processa perante um interlocutor, representado pelo leitor ou pelo "eu" tornado objeto de si próprio. Como que ao espelho, o "eu" se narra interminavelmente, retomando sempre de ponto diverso o círculo em espiral de sua ansiosa indagação (MOISÉS, 1985, p. 458).

Juntando-se ao posicionamento da crítica e ao amadurecimento estético da escritora, os contos de Laços de Família tornaram-se um dos pontos altos de nossa prosa nacional. Na obra, as entediadas e infelizes personagens são "iluminadas" pelo processo conhecido como epifania pelos detalhes cotidianos: rosas perfeitas sobre a mesa, um cego mascando chicletes, a exuberância do Jardim Botânico, um toque de ombros entre mãe e filha numa intimidade de corpo há muito desconhecida, e num piscar de olhos um novo mundo se apresenta violentamente para esses personagens.
Afrânio Coutinho (2001) afirma que Laços de Família tornou-se o fenômeno literário que é hoje, pouco mais de 50 anos de sua primeira publicação, pelo fato de que a vantagem da narrativa curta para a autora está em que ela evita as tiradas filosofantes, reduz o vício da intelectualização e a subjetivação da realidade. Porém, as frases curtas, compostas de palavras diárias, são renovadas ciladas para o leitor menos avisado. Aos poucos, compreendemos a complexidade contida nessas pequenas histórias.

Já Moisés (apud SÁ, 1979), em um artigo intitulado Clarice Lispector: contista, publicado em 1961, afirma que Clarice transborda do conto e o seu talento para a lentidão e o microscópico não se ajusta à rapidez da história curta. Assim, a tendência subjacente da escritora para o romance pode tornar-se manifesta, basta juntar os contos todos pelo seu núcleo dramático, abstraindo certos incidentes particulares, e se terá a atmosfera do romance. Para Moisés, a linguagem de Clarice em Laços de Família, é plástica, maleável, forte a ponto de não perder o aprumo e ser capaz de insinuar os subjetivismos duma retina atenta para os mínimos gestos.

Em 1961, um ano após a publicação, Laços de Família recebe o prêmio Jabuti de Literatura na categoria "Contos, crônicas e novelas". Intelectuais da época também manifestaram sua apreciação pelo trabalho da escritora por meio de cartas: Fernando Sabino afirma que a obra seria exata, sincera, indiscutível e até humildemente o melhor livro de con- 
tos publicado no Brasil e Érico Veríssimo afirma que Laços de Família é a mais importante coleção de histórias publicadas neste país na era pós-machadiana.

A paixão segundo G.H., publicada em 1964, obra que Alfredo Bosi (2006) intitula de romance de educação existencial, marca, ao lado de Laços, o ponto alto da carreira da escritora. A linhagem de personagens clariceanas em busca do núcleo da existência prossegue de modo mais radical neste que é um dos romances mais insólitos da autora. Desde sua abertura - a possíveis leitores -, o livro quebra com as expectativas de um romance tradicional a ser digerido por um leitor passivo. Clarice se preocupou com o receptor de seus textos, demonstrando ter consciência da necessidade de identificação do leitor com sua obra, como podemos perceber neste aviso esclarecedor:

\begin{abstract}
A possíveis leitores
Este livro é como um livro qualquer. Mas eu ficaria contente se fosse lido apenas por pessoas de alma já formada. Aqueles que sabem que a aproximação do que quer que seja se faz gradualmente e penosamente - atravessando inclusive o oposto daquilo que se vai aproximar. Aquelas pessoas que, só elas, entenderão bem devagar este livro nada tira de ninguém. A mim, por exemplo, o personagem G.H. foi dando uma alegria difícil; mas chama-se alegria. C.L. (LISPECTOR, 1964, p. 7).
\end{abstract}

Em $O$ drama da linguagem: Uma leitura de Clarice Lispector, Benedito Nunes (1995) nos apresenta um capítulo bastante elucidativo a respeito do romance em questão, intitulado de $O$ itinerário místico de G.H. Esse mesmo capítulo já teria feito parte de outros textos do autor que contemplam a obra da escritora. No ensaio inicial sobre Clarice Lispector (1966) e, posteriormente, na obra Leitura de Clarice Lispector (1973), o romance recebeu uma interpretação mais concisa e o título A experiência mística de G.H.

Para Nunes (1973, 1995), o momento de compreensão do mundo e de si mesma ocorre quando a protagonista entra no quarto da empregada que acaba de sair do emprego e vê uma barata saindo do guarda-roupa. Este inseto muda a compreensão da existência de G.H., porque condensam-se pouco a pouco, em torno do inseto, sentimentos contraditórios que vão crescendo. Na visão do crítico, G.H. passa da comum aversão das donas de casa por baratas, o simples nojo físico, o medo, até o súbito interesse despertado pelo inseto caseiro dão lugar a uma estranha coragem, misto de curiosidade e de impulso sádico-masoquista com que G.H. fechando a porta do guarda-roupa sobre $o$ corpo do animal, perpetra $o$ ato decisivo.

Quando a protagonista vê a barata esmagada, o nojo se aprofunda, a ponto de secar-lhe a boca e revirar-lhe o estômago, transformando-se em náusea.

Como chamar de outro modo aquilo horrível e cru, matéria-prima e plasma seco, que ali estava, enquanto eu recuava dentro de mim em náusea seca, eu caindo séculos e séculos dentro de uma lama - era lama, e nem sequer lama já seca, mas lama ainda úmida e viva era lugar onde remexiam com lentidão insuportável as raízes da minha identidade (LISPECTOR, 1964, p. 58).

Para o crítico e escritor Assis Brasil (1973), embora A paixão segundo G.H. pareça, à primeira vista, um caminho 
novo ou diferente na obra de Clarice, é o resultado mais objetivo de um pensamento desenvolvido no decorrer de todos os seus livros. Para melhor entendimento do romance, o crítico nos alerta que devemos partir da leitura de $A$ maçã no escuro, pois tal romance é o passo anterior à Paixão, em que a autora tenta cristalizar seu pensamento. O teórico, concordando com Benedito Nunes, chama a atenção da crítica literária que terá de se sentir na obrigação de abordar aspectos até certo ponto extraestéticos da atividade criadora de Clarice Lispector, sem dúvida alguma interligados, intimamente, com o seu processo de se exprimir perante o mundo.

Finalizando seu estudo, Assis Brasil aponta que a técnica narrativa de Lispector em A paixão segundo G.H. é diferente no quadro de seus livros anteriores, pois não é melhor nem mais convincente do que qualquer outra usada pela autora. Tampouco é suficiente como realização no plano criativo - não é orgânica nem se organiza como o pensamento central da obra. A cristalização das intenções estilísticas da escritora, que propomos para este segundo momento do trabalho, ficam claras nas palavras do crítico:

Talvez as intenções de Clarice Lispector tenham sido outras ao criar G.H., ou talvez também não se tenha apercebido das implicações múltiplas de um trabalho que está mais situado no campo do conhecimento do que no campo da ficção. A paixão é o resultado de uma experiência das mais novas e ousadas da ficção brasileira. E por isso a autora se inscreve aqui como um dos nomes que constroem uma obra dentro de nova mentalidade e novos recursos estéticos ((BRASIL, 1973, p. 76, grifo nosso).
Analisando a trajetória dos personagens de Clarice Lispector, o crítico José Américo Motta Pessanha, em um ensaio intitulado Itinerário da Paixão, publicado em 1965, afirma que o percurso de $A$ paixão segundo G.H., já estava traçado e prometido em toda a obra anterior da escritora.

Era o rio subterrâneo, um rio de água poluída, o fluente e selvagem coração da vida. A seiva oculta, o mal secreto, que nutria os personagens, todos arautos do mesmo vento, todos preparadores do mesmo caminho. $\mathrm{O}$ subsolo da obra clariceana. Se a superfície o terreno se acidentou em contos, em longas extensões de romance ou se estilhaçou em breves anotações foi porque a superfície da obra acompanhou e refletiu abalos sísmicos profundos. A obra clariceana, abriga a gestação de uma visão de mundo que só podia terminar em A paixão. Uma espécie de itinerário oculto, em busca da raiz do ser-em-si (PESSANHA, 1965, p. 23).

$\mathrm{O}$ único posicionamento negativo da crítica que encontramos nesse período em discussão é o de Luis Costa Lima (apud SÁ, 1979) que põe em cheque toda a estrutura do universo ficcional da autora. Na verdade, para Costa Lima, todos os romances publicados até 1961 são de pouco fôlego, por efeito da sua desarticulação com a totalidade concreta, em que a subjetivação intelectualizada supre a falta de realidade e termina por esmagar as personagens e a matéria novelesca. Novamente o que se nota é uma rejeição diante do novo e a falta de preparo para recebê-lo. Porém, ao ler $A$ paixão segundo G.H., o crítico escreve o ensaio A mística ao revés de Clarice Lispector, publicado em 1966, afirmando 
que apesar de tratar-se da mais abstrata das obras da escritora, é, entretanto, aquela em que o resultado do imaginário aponta mais diretamente para a reimersão da realidade.

\section{Wilma Arêas e a hora do lixo}

Desde a publicação de $A$ paixão segundo G.H. até o terceiro momento deste trabalho, que consiste na publicação dos contos de A via crucis do corpo, em 1974, passaram-se exatos dez anos. Dentre as obras que Clarice Lispector publicou neste ínterim, duas merecem destaque: Os contos de Felicidade Clandestina, em 1971, muitos deles já conhecidos pelos leitores do JB e grande parte deles também já publicados em uma coletânea de 1964, intitulada A legião estrangeira, e ainda, Água Viva, em 1973, texto de difícil definição, como a própria autora-narradora do livro afirma: "é inútil querer me classificar; eu simplesmente escapulo não deixando, gênero não me pega mais" (LISPECTOR, 1978, p. 17). Trata-se mesmo de um texto líquido, como sugere o título, em que a narrativa se derrama numa fluidez altamente poética e radicalmente existencial.

Os leitores de Água Viva tomaram um choque semelhante àquele produzido pela leitura de Perto do Coração Selvagem, há 30 anos. Mesmo com todo o material já pesquisado e publicado a respeito de sua ficção, a escritora desnorteou a crítica literária mais uma vez, que ora parecia não compreendê-la, ora procurava influências. A constatação é inevitável: Clarice Lispector de uma maneira geral é promessa de leitura difícil e intranquila e, por isso, não satisfaz de imediato, a preferência literária. Deixá-la de lado era mais confortável do que tentar decifrá-la (LIBANORI, 2002, p. 14). Porém, talvez seja esse enigma que faz com que Clarice possa contar com o aplauso de um público mais afeito às experiências ousadas. Recorremos novamente a Roland Barthes para fundamentarmos esta afirmação.

Em O prazer do texto (1996), Barthes diz que o que dá prazer ao leitor não é o óbvio, mas aquilo que fica sugerido, que instiga. Para ele, o prazer que o escritor experimenta ao escrever não garante 0 prazer de seu leitor. É esse imprevisto que faz com que o texto seja um espaço de fruição. Não é o certo que atrai, mas as incertezas, aquilo que não pode ser apreendido que faz com que o texto seja instigante. Segundo Barthes, por um lado, o texto teria duas margens: uma mais sensata, previsível, que faz uso da língua que se conhece, fruto da convenção social; e, por outro, haveria uma segunda margem móvel, na qual ocorreria a morte dessa mesma linguagem, para a criação de outros sentidos. A fruição do texto e 0 seu valor estariam presentes no espaço entre essas duas margens. Um texto realmente de valor deveria para ele obrigatoriamente apresentar essas duas faces.

Assim sendo, podemos afirmar que Clarice Lispector escreve textos de fruição, pois, na maioria das vezes, suas obras desconfortam, desconstroem o leitor, seja do ponto de vista histórico, cultural ou 
psicológico. É característica do texto de fruição o que encontramos na autora: quebra de regras estabelecidas. Desde seu surgimento, passando por todos esses importantes momentos que citamos neste trabalho, Clarice trouxe o novo, o que sempre alarga a distância estética, algo que revê a relação entre texto e linguagem, estabelecendo outras relações de sentido que se lança em um tempo que não o seu justamente por essa quebra de convenções. Barthes afirma que texto de qualidade, isto é, de fruição, não pode ser absolutamente claro, ao contrário, deve possuir suas sombras. É nessas sombras que está seu potencial. Ele não faz parte de uma ideologia dominante, ou seja, não está inserido somente em um padrão já esperado. Ele deve possuir locais ocultos, entranhas que permitem que jamais seja dominado totalmente.

No entanto, um ano após a densidade de Água Viva, a autora novamente surpreende seus leitores. Mas, não se trata de uma experiência ainda mais radical em sua estrutura ficcional ou na contínua preocupação com a existência de seus personagens. Em 1974, divorciada de seu marido, com filhos para sustentar, Clarice Lispector se encontra em uma delicada situação econômica e, então, aceitando o pedido de seu editor, escreve por encomenda, atividade que já havia realizado há muitos anos. Os teóricos tentam explicar o fracasso literário que esta obra se tornou levando-se em conta os problemas financeiros e o curto espaço de tempo que a escritora teve para produzir.
A crítica pouco se pronunciou a respeito dessa obra. Não há registros de contribuições de Benedito Nunes que, como sabemos, foi o teórico que estudou toda a obra de Lispector. A autora de A via crucis do corpo é totalmente diferente da escritora de Perto do Coração Selvagem, de A paixão segundo G.H. ou ainda da escritora de Água Viva do ano anterior e os leitores, mais uma vez, estranharam seu estilo.

Clarice recorre ao prefácio da obra Explicação - não a fim de preparar o espírito de seus leitores para a possibilidade de uma leitura difícil (como foi no caso de G.H.), mas para esclarecer a gênese da obra e suas possíveis implicações:

\section{Explicação}

O poeta Álvaro Pacheco, me encomendou três histórias que realmente aconteceram [...] Comecei no sábado. No domingo de manhã as três histórias estavam prontas [...] Eu mesma espantada. Todas as histórias deste livro são contundentes. E quem mais sofreu fui eu mesma. Fiquei chocada com a realidade. Se há indecências nas histórias não é culpa minha. Inútil dizer que não aconteceram comigo, com minha família e com meus amigos. Como é que sei? Sabendo. Artistas sabem das coisas. Quero apenas avisar que não escrevo por dinheiro e sim por impulso. Vão me jogar pedras. Pouco importa. Não sou de brincadeiras, sou mulher séria. Além do mais tratava-se de um desafio (p. 11) Só peço a Deus que ninguém me encomende mais nada. Porque, ao que parece, sou capaz de revoltadamente obedecer, eu a inliberta. Uma pessoa leu meus contos e disse que aquilo não era literatura, era lixo. Concordo. Mas há hora para tudo. Há também a hora do lixo (grifo nosso). Este livro é um pouco triste porque eu descobri como criança boba, que este é um mundo cão (LISPECTOR, 1998, p. 12). 
A obra foi bem recepcionada pela crítica feminista liderada por Wilma Arêas que, com a obra Clarice Lispector: Com a ponta dos dedos (2005), realizou um estudo com o qual buscava lançar novas luzes àquela obra tão mal vista, intencionando, dessa maneira, colaborar para a reconstrução desse novo horizonte de expectativas. A pesquisadora afirma que a autora estava ciente de que se lançava em um projeto de escrita libertária que mostraria o cotidiano dos seres, em sua mais primitiva condição humana, focalizando a figura da mulher exposta a um enfrentamento de suas próprias carências e traumas. Segundo Arêas (2005), as treze narrativas giram em torno de mulheres e das necessidades do corpo e suas exigências, de maneira que a linguagem e o cenário erótico contribuem para o arranjo e o desfecho de todas as histórias.

O diálogo com o tema religioso é iniciado pelo título que dialoga com o discurso bíblico da "via sacra", "via crucis", caminho da cruz e a relação entre o sagrado (via crucis) e o profano (do corpo) acontece no título A via crucis do corpo. Esse corpo pode ser entendido como o corpo humano, a carne, ou também como o corpo do texto.

Pela primeira vez na sua literatura, 0 sexo aparece de forma tão direta e brutal. Para Arêas (2005), os tabus sexuais são tratados por ela com a naturalidade de quem conhece perfeitamente a ótica feminina e que não tem medo de expor seus desejos e anseios. Lispector reclama a posse do corpo feminino e o retrata cursando a sua verdadeira "via crucis".

Clarice Lispector, mesmo tendo que escrever um livro sob encomenda, em que trata de um assunto tão polêmico como o sexo, não deixa de mostrar ao leitor que a escrita de A via crucis do corpo é um desafio e que, mesmo assim, sentia nela "nascer a inspiração" diante da arte da palavra. Lispector, conforme nos diz Arêas (2005), ao compor os textos dessa obra, apresenta histórias carregadas de um humor irônico revelado tanto na popularidade de seus personagens, quase sempre de classe baixa (os contos abordam prostitutas, travestis, mendigos e marginais que vagueiam pelas noites cariocas), quanto nos acontecimentos absurdos mesclados de erotismo e melancolia que formam as histórias.

Deixando de lado todo um alicerce que a crítica havia sedimentado num período de trinta anos, desde suas primeiras conquistas ainda jovem, com Perto do Coração Selvagem até a densa escrita fragmentária de Água Viva, Wilma Arêas (2005) afirma que em A via crucis, Clarice Lispector prova ao leitor que não se restringe apenas a temas abstratos ou de cunho existencialista, mostra que não está alheia à realidade do mundo e que tem a rara sensibilidade de lidar com os mais diversos temas de forma natural, como viver é natural, o sexo faz parte da vida; por meio de um discurso irônico.

Rosenbaum (2002) que também analisa a obra da autora pela ótica feminista é menos radical que Arêas, pois promove 
um olhar para a questão da mulher, mas não descarta as contribuições filosóficas que eternizaram a escritora, fazendo um elo entre os aspectos sincrônicos e diacrônicos no decorrer da recepção da obra clariceana, isto é, a pesquisadora aponta a transcendência da obra de Lispector e a articula à história de nossa literatura.

Essa dupla face da obra clariceana - a temática existencial, filosófica ou metafísica e a vertente realista, social, mediada sobretudo (mas não só) pela condição histórica da mulher - é sua característica predominante. A realidade e a linguagem, assim como o viver e o escrever, caminham inexoravelmente juntas na obra da autora, mesmo que os textos se inclinem ora a um ora a outro pólo mais proeminente (ROSENBAUM, 2002, p. 87).

\section{Considerações finais}

A crítica literária e sua atividade recepcional é um discurso indispensável para a apreciação e o manuseio de um texto ficcional. Completando essa afirmação, Barthes (2003, p. 226) diz: "Certamente, a crítica é uma leitura profunda, ela descobre na obra certo inteligível, e nisso, é verdade, ela decifra e participa de uma interpretação".

Chegamos ao fim deste panorama crítico/recepcional da obra de Clarice Lispector e muito ficou por comentar. Trata-se de uma escritora que tem sua obra lida e respeitada pelos maiores estudiosos de literatura do Brasil, por isso, as contribuições são muitas, os estudos vastos. Porém, esperamos ter esclarecido a questão fundamental que norteou o nosso trabalho, ou seja, apon- tar a recepção da crítica em três importantes momentos da trajetória literária de Lispector.

A autora foi bem recebida, posta no rol dos maiores escritores brasileiros e posteriormente mal vista, graças ao posicionamento da crítica, que acompanhou sua obra, carimbando-a eternamente com suas palavras: ficcionista do tempo para uns, escritora das sutilezas da alma para outros, a verborrágica que gosta de falar difícil, a mística preocupada com questões existenciais, a introspectiva, enfim, as classificações continuarão a suceder-se, tentando abarcar um estilo rebelde a todos.

A questão é simples. Se Clarice Lispector foi considerada autora de um estilo tão problematizador da linguagem e da vida, se representou uma ruptura com a tradição literária de seu tempo e se tem sua marca registrada na obra de grandes escritores contemporâneos como Lygia Fagundes Telles, Dalton Trevisan, Rubem Fonseca, Caio Fernando Abreu, João Gilberto Noll, todos conscientes de terem sido precedidos pela sua singular literatura e, ainda, se é tema dos mais variados estudos, como esse, por exemplo, podemos simplesmente dizer que é a crítica realizando sua mais nobre função. 


\section{Critical reception of Clarice Lispector: decisive moments}

\section{Abstract}

The following work aims to bring reflections about the critical acceptance over Clarice Lispector in three different moments, meant decisive in her work: her professional arise with Perto do Coração Selvagem (Closer to the Wild Heart), in 1944, debut romance wich opened a new narrative style until then unknown at our country; the higher point at her career, with the publication of the collection Laços de Família ( $F a$ mily Bounds), in 1960, and with the romance A Paixão Segundo G.H. (The Passion According to G.H.), in 1964, words upon her mature stage, wich crystallizes all of her formal traits and existential concerns that would place her as the main names of our literary history, and finally, with one of her last publications: A via crucis do corpo (The Body's via crucis), from 1974, where, engaged in writing on demand, the critics flagged a esthetic values decay and at the traits and technics wich flowed through her writing along her whole work.

Keywords: Clarice Lispector. Literary critic. Literary reception.

\section{Notas}

A primeira edição é de 1934.

A primeira edição é de 1966.

De acordo com Jauss (1994), o horizonte de expectativas engloba o limite do que é visível e está sujeito a alterações e mudanças, conforme as perspectivas do leitor. O horizonte de expectativas é responsável pela primeira reação do leitor frente à obra, pois se encontra na consciência individual como um saber cons- truído socialmente e de acordo com o código de normas estéticas e ideológicas de uma época, e pode variar no decorrer do tempo.

4 Para Jauss (1994) é distância estética as expectativas entre o leitor e sua realização. Tal distância determina o caráter artístico de uma obra.

\section{Referências}

ARÊAS, Vilma. Clarice Lispector: Com a ponta dos dedos. São Paulo: Companhia das Letras, 2005.

ARRIGUCI JÚNIOR, David. Leitura: entre o fascínio e o pensamento. São Paulo: FDE, 1994.

BARTHES, Roland. Crítica e verdade. Tradução Leyla Perrone-Moisés. São Paulo: Perspectiva, 2003.

$$
\text { O prazer do texto. Tradução }
$$

Jaime Guinsburg. São Paulo: Perspectiva, 1996.

BOSI, Alfredo. História concisa da literatura brasileira. São Paulo: Cultrix, 2006.

BRASIL, Assis. História crítica da literatura brasileira: A nova literatura. I - O romance. Rio de Janeiro: Americana, 1973.

CANDIDO, Antonio. Vários Escritos. São Paulo: Livraria Duas Cidades, 1970.

COUTINHO, Afrânio. A literatura no Brasil. Rio de Janeiro: José Olympio, 2001.

FRYE, Northrop. Anatomia da crítica. Tradução Péricles Eugênio da Silva Ramos. São Paulo: Cultrix, 1973.

JAUSS, Hans Robert. A história da literatura como provocação à teoria literária. São Paulo: Ática, 1994.

LIBANORI, Évely Vânia. Água Viva: O processo criador de Clarice Lispector e o papel do leitor. Dissertação (Mestrado em Teoria da Literatura e Literaturas de Língua Portuguesa) - Universidade Estadual Paulista. São Paulo, 2002. 
LIMA, Luis Costa. Por que literatura. Petrópolis: Vozes, 1966.

LINS, Álvaro. Os mortos de sobrecasaca: ensaios e estudos (1940-1960). Rio de Janeiro: Civilização Brasileira, 1963.

LISPECTOR, Clarice. Água viva. Rio de Janeiro: Francisco Alves, 1994.

A paixão segundo G.H. Rio de Janeiro: Rocco, 1964.

. A via crucis do corpo. Rio de Janeiro: Rocco, 1998 a.

. Laços de família. Rio de Janeiro: Rocco, 1998b.

Perto do coração selvagem. Rio de Janeiro: Nova Fronteira, 1980.

MILLIET, Sérgio. Diário crítico. v. II. São Paulo: Martins, 1981.

Martins, 1981.

Diário crítico. v. III. São Paulo:

MOISÉS, Massaud. História da literatura brasileira: Modernismo. São Paulo, Cultrix, 1985.

NUNES, Benedito. Leitura de Clarice Lispector. São Paulo: Quirón, 1973.

O drama da linguagem: Uma leitura de Clarice Lispector. São Paulo: Ática, 1995. $O$ dorso do tigre. São Paulo: Perspectiva, 1969.

PERRONE-MOISÉS, Leyla. Inútil Poesia. São Paulo: Companhia das Letras, 2000.

PESSANHA, José Américo Motta. Itinerário da Paixão. Rio de Janeiro: Cadernos brasileiros, 1965.

POUND, Ezra. O abc da literatura. Tradução Augusto de Campos e José Paulo Paes. São Paulo: Cultrix, 2006.

ROSENBAUM, Yudith. Clarice Lispector. São Paulo: Publifolha, 2002.

SÁ, Olga de. A escritura de Clarice Lispector. São Paulo: Vozes, 1979. 